\title{
Effects of Wood Species, Number of Teeth, and Adhesive Type on Moment Capacities of Box-Joints
}

\author{
Selçuk Demirci, ${ }^{\mathrm{a}}$ Harun Diler, ${ }^{\mathrm{b}}$ Ali Kasal, ${ }^{\mathrm{c}}$ and Yusuf Ziya Erdil ${ }^{\mathrm{c}, *}$ \\ Effects of the wood species, number of teeth, and adhesive type were \\ studied relative to the moment capacities of box joints under tension and \\ compression loadings, which is commonly used in case type solid wood \\ furniture. For this purpose, L-type specimens were prepared from Scotch \\ pine (Pinus sylvestris L.), poplar (Populus sp.), and fir (Abies sp.). \\ Polyvinyl acetate (PVAc) and polyurethane (PU) adhesives were used in \\ the preparation of joints. Tension and compression tests with 360 samples \\ were performed under static loading. According to the results, the highest \\ moment capacities were obtained for Scotch pine under tension, and \\ poplar specimens under compression. With respect to the number of teeth, \\ the highest moment capacities were obtained with 12-tooth joints under \\ both tension and compression loadings. For adhesive types, the \\ specimens glued with PVAc gave better results in both tension and \\ compression. In manufacturing of solid wood based case-type furniture, \\ the higher number of teeth resulted in a slightly better performance; \\ however, the results with the 4-tooth structure was not too far from 8-tooth. \\ Furthermore, it was concluded that Scotch pine as a substance and PVAc \\ as adhesive could be recommended.
}

Keywords: Case construction; Wood; Box-joint; Tension; Compression; Moment capacity

Contact information: a: Department of Wood Science and Furniture Design, Ege University, 35000, Izmir, Turkey; b: Department of Furniture Design, School of Technical Sciences, Akdeniz University, 07000, Antalya, Turkey c: Department of Woodworking Industrial Engineering, Faculty of Technology, Mugla Sitki Kocman University, 48000, Kotekli, Mugla,Turkey; *Corresponding author: erdil@mu.edu.tr

\section{INTRODUCTION}

In the construction industry there are four types of furniture categories, namely frame, case, crust, and combination types. Case-type furniture construction is widely utilized with both solid wood and wood-based panels. The assembly of case-type furniture could be made with adhesive or with a variety of connectors such as knock-down fasteners, minifix, screws, etc. A box-joint is commonly used, especially when the construction involves use of an adhesive. Box-joinery creates a wider surface area and a chance of interlocking the wood members in order to create a robust joint via the substance's own strength. There are variety of traditional and contemporary box-joints, such as butt-joint, dowelled, biscuit, splined, lock, finger, and dovetail, etc. Due to the fact that the box-joints typically are very robust, they have been widely used in wooden furniture in the past and present. In particular, box-joints are preferred for the drawers of the furniture, as such elements are in frequent motion.

Box joints are actually multiple interlocking finger joints with many different configurations. Chan (2002) indicated that even though they are commonly associated with drawers, larger boxes such as pedestals and cabinets could be manufactured with boxjoints. The most prominent advantage of box-joints is that they could be sawn by hand or 
conventional table saw, they can also be cut in precision with state of the art CNC technology. Murphey and Rishel (1972) claimed long ago that finger joints could be a replacement for mortise and tenon or dowel joints in furniture production.

Polyvinyl acetate (PVAc) and polyurethane (PU) adhesives are widely used in furniture joinery because their formulas allow them to cure under ambient temperatures. While PVAc has had a more extensive history of use as an adhesive, research has shown that one-part PU (Lange et al. 2001) and two-part PU (Chen and Walworth 2001) both could be employed in structural finger joints.

According to Nicholls and Crisan (2002), box-type of furniture is subjected to both static and dynamic loads. Thus, the joints of such furniture pieces have to be strong and stiff enough to endure these loads. Ors et al. (2003) studied dovetail corner joints. They found the highest bending strength with okoume plywood, and the lowest bending strength values with solid Scotch pine and poplar, respectively. However, considering the technical and economic factors, the use of wood-based composite materials is recommended in the production of case furniture. Kamboj et al. (2019) studied the effect the geometry on the elastic stiffness of finger corner joints. They analyzed the factors of wood species, adhesive type, and number of teeth. The study revealed that the highest stiffness values were obtained with 5-tooth beech with PVAc under tensile loads, while the lowest values were obtained with 2-tooth spruce bonded with PVAc under compression. Efe and Imirzi (2008) found higher moment values on plywood and medium density fiberboard (MDF) corner joints assembled with glue and screw. The experimental samples prepared with 18 $\mathrm{mm}$ thickness gave better results than $16 \mathrm{~mm}$ panel thickness. However, the $16 \mathrm{~mm}$ thick materials showed applicability from technical and economic aspects. Ustundag (2008) studied the diagonal compression and tension performance of dovetail corner joints with PU-based and PVAc-based adhesives. He found the highest compression performance on Oriental beech with PU based adhesive; while the lowest was of MDF with PVAc adhesive. Atar et al. (2010) studied the effect of adhesives on corner joints under diagonal tension and compression. They found the highest diagonal tension values in European oak with PVAc glue, while the lowest value was obtained in MDF with PU based adhesive. They concluded that PVAc as glue could be suggested to obtain some advantages on the dovetail joint process for box-type furniture made from both solid wood and MDF.

Freedman (1997) has noted that the strength of box joints comes from interlocking fingers, which create large glue surface area. Some researchers (Ayarkwa et al. 2000; Bustos et al. 2011; Franke et al. 2014) argued that the strength of box joints are associated with surface area. However, there has been no robust demonstration that the surface area, i.e. the number of teeth, is directly related to high strength of joint. Furthermore, as can be seen from the literature, the effect of adhesive is inconclusive when it comes to decide between PVAc and PU in box-joints. Therefore, in this study, it was aimed to compare the effects of the number of teeth, wood species, and adhesive type on moment capacity of box-joints under diagonal compression and tension.

\section{EXPERIMENTAL}

\section{Materials and Methods}

In this study, specimens were prepared with Scotch pine (Pinus sylvestris L.), poplar (Populus sp.), and fir (Abies sp.). The adhesive type used were polyvinyl acetate 
(PVAc), and polyurethane (PU). Corner joints were prepared as box-type joints with three different numbers of teeth, namely 4,8 , or 12 teeth.

Wood materials were kept at $20{ }^{\circ} \mathrm{C} \pm 2{ }^{\circ} \mathrm{C}$ and at $65 \% \pm 3 \%$ relative humidity until their weight became stable in an environmentally controlled conditional chamber. Moisture contents (MC) and densities of the wooden materials were measured according to TS 2471 and TS 2472 standards, respectively. MC, density, MOR, and MOE values of woods used in testing are given in Table 1. In this study, three different tooth configurations were utilized. Box-joints were prepared under laboratory conditions using a table saw and a box joint jig with a stacked dado set. The clearance of notch and finger was near kept near $0+/-$ $0.01 \mathrm{~mm}$ in order to ensure a snug fit. Assembly was done with an application of thin but thorough layer of adhesive. Corner joints were then clamped together and kept clamped and kept in laboratory for 24 hours until the adhesives were totally cured. The 3D configurations and dimensions of the specimens are given in Figs. 1 and 2.

The total number of specimens was 360: 3 wood species (Scotch pine, poplar, and fir), 2 adhesive types (PVAc and PU), 3 different tooth numbers $(4,8$, and 12 tooth) $\times 2$ loading type (tension and compression strength) $\times 10$ replications $(3 \times 2 \times 3 \times 2 \times 10=360)$.

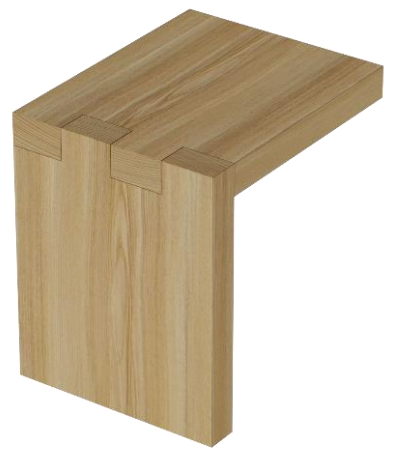

(a)

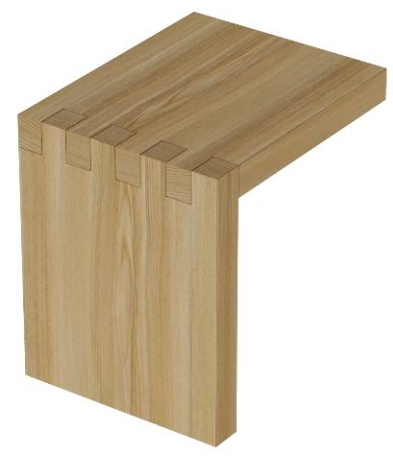

(b)

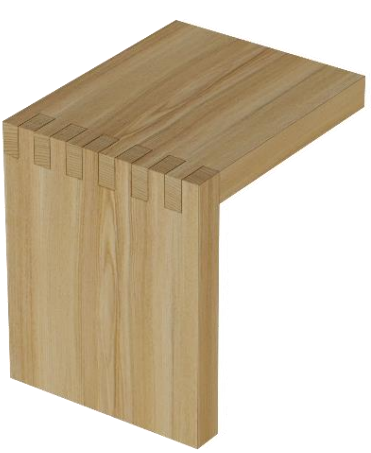

(c)

Fig. 1. 3D Specimen configurations: 4-tooth (a), 8-tooth (b), and 12-tooth (c)

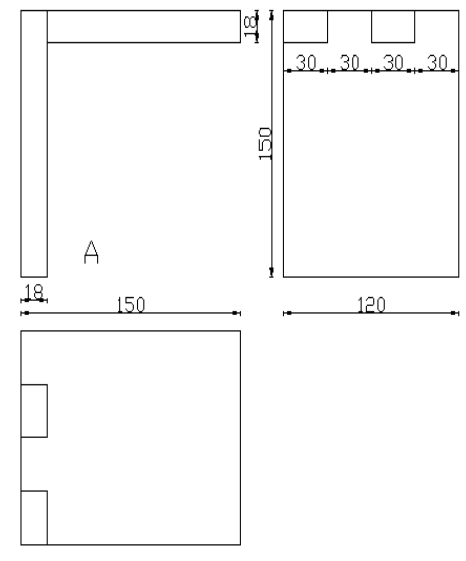

(a)

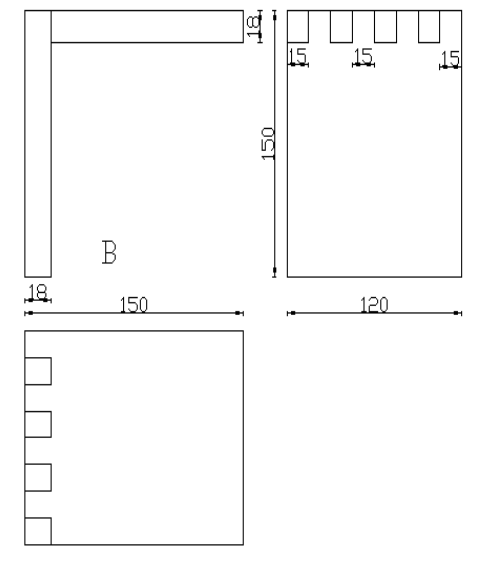

(b)

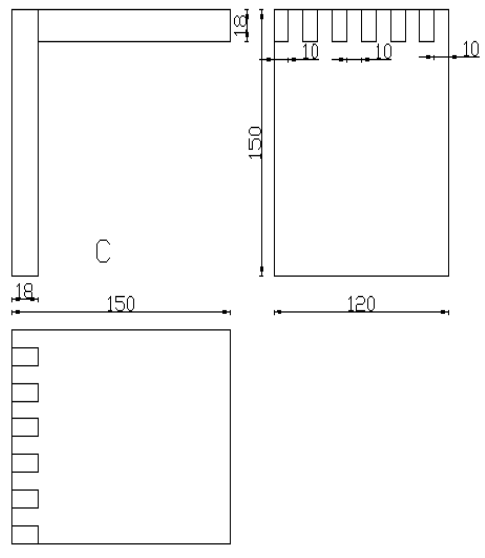

(c)

Fig. 2. Specimen dimensions (in $\mathrm{mm}$ ): 4-tooth (a), 8-tooth (b), and 12-tooth (c)

Tests were carried out in a Universal testing machine with specimens prepared according to the procedures outlined in ASTM-D 143-83 (1983). The rate of the static 
loading was $2 \mathrm{~mm} / \mathrm{min}$. Test set-up is shown in the Fig. 3. Maximum loads read from the test machine were recorded in units of Newton.

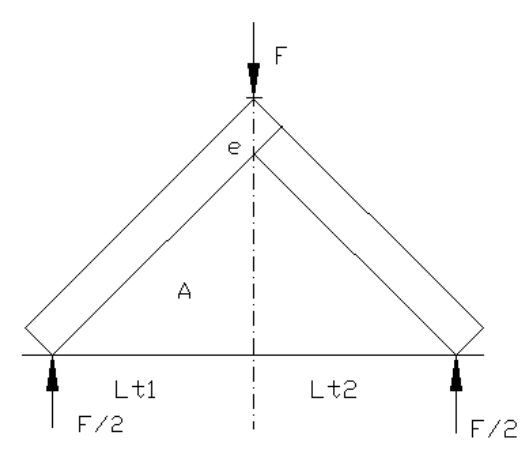

(a)

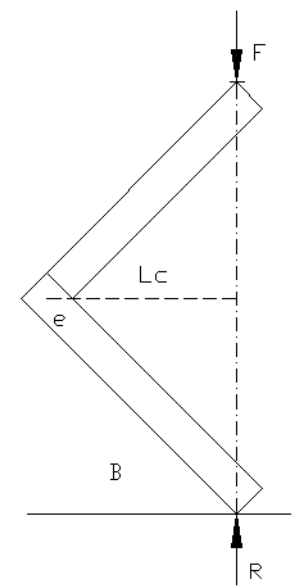

(b)

Fig. 3. Method of loading: tension (a) and compression (b)

Because the supports are outside in the diagonal tension tests and the joint is out of force direction in diagonal compression tests, the moment force (M) occurs at the corner joints. Moment is calculated from Eqs. 1 and 2 for diagonal tension and diagonal compression tests, respectively,

$$
\begin{aligned}
& M_{\mathrm{t}}=0.5 F_{\max } x L_{\mathrm{t} 1}\left(\text { or } L_{\mathrm{t} 2}\right) \\
& M_{\mathrm{c}}=F_{\max } x L_{\mathrm{c}}
\end{aligned}
$$

where, $M_{\mathrm{t}}$ is the moment in diagonal tension and $M_{c}$ is the moment in diagonal compression $(\mathrm{Nm}), F_{\max }$ is the ultimate force at time of failure $(\mathrm{N}), L_{\mathrm{t} 1}, L_{\mathrm{t} 2}$ is perpendicular distance from the point force applied to supports $(\mathrm{m})$, and $L_{\mathrm{c}}$ is horizontal distance from force applied to the rotation point $(\mathrm{m})$. The moment $\operatorname{arm}\left(L_{\mathrm{t} 1}, L_{\mathrm{t} 2}, L_{\mathrm{c}}\right)$ was calculated as $0.0933 \mathrm{~m}$ for both compression and tension loads.

Table 1. MC, Oven-dry and Air-dry Density, MOR, and MOE of the Specimens

\begin{tabular}{|c|c|c|c|c|c|}
\hline $\begin{array}{c}\text { Wood } \\
\text { Species }\end{array}$ & $\begin{array}{c}\text { MC } \\
(\%)\end{array}$ & $\begin{array}{c}\text { Oven-dry Density } \\
\left(\mathrm{g} / \mathrm{cm}^{3}\right)\end{array}$ & $\begin{array}{c}\text { Air-dry Density } \\
\left(\mathrm{g} / \mathrm{cm}^{3}\right)\end{array}$ & $\begin{array}{c}\text { MOR } \\
(\mathrm{MPa})\end{array}$ & $\begin{array}{c}\text { MOE } \\
(\mathrm{MPa})\end{array}$ \\
\hline Scotch pine & 11.2 & 0.49 & 0.52 & 75.8 & 12135 \\
\hline Poplar & 10.8 & 0.46 & 0.50 & 74.4 & 9859 \\
\hline Fir & 11.3 & 0.40 & 0.44 & 69.6 & 10894 \\
\hline
\end{tabular}

\section{RESULTS AND DISCUSSION}

In general, specimens both under compression and tension showed a similar mode of failure in which the joints did not show any sign of failure until an abrupt loss of strength occurred. The observation showed glue line failure in virtually all specimens. In other words, no failure was observed on the notches or fingers. The minimum, maximum, average ultimate forces under diagonal tension of tested joints with their coefficients of variation are summarized in Table 2. Table 3 summarizes the forces recorded under diagonal compression with their coefficients of variation. 
Table 2. Ultimate Force Results Under Diagonal Tension for Box-type Joints

\begin{tabular}{|c|c|c|c|c|c|c|c|}
\hline $\begin{array}{l}\text { Wood } \\
\text { Species }\end{array}$ & $\begin{array}{l}\text { Adhesive } \\
\text { Type }\end{array}$ & $\begin{array}{l}\text { Number of } \\
\text { Teeth }\end{array}$ & $\begin{array}{l}\text { Number of } \\
\text { Replications }\end{array}$ & $\begin{array}{l}\text { Minimum } \\
\text { Value }(\mathrm{N})\end{array}$ & $\begin{array}{l}\text { Maximum } \\
\text { Value }(\mathrm{N})\end{array}$ & $\begin{array}{c}\text { Mean } \\
\text { Value } \\
(\mathrm{N})\end{array}$ & $\begin{array}{c}\text { Coefficients } \\
\text { of Variation } \\
(\%)\end{array}$ \\
\hline \multirow{6}{*}{$\begin{array}{l}\text { Scotch } \\
\text { Pine }\end{array}$} & \multirow{3}{*}{ PVAc } & 4 & 10 & 2700 & 3300 & 2990 & 5.8 \\
\hline & & 8 & 10 & 2300 & 3400 & 2800 & 10.9 \\
\hline & & 12 & 10 & 3900 & 4800 & 4350 & 8.1 \\
\hline & \multirow{3}{*}{ PU } & 4 & 10 & 1700 & 2200 & 1910 & 8.4 \\
\hline & & 8 & 10 & 2300 & 3400 & 2610 & 11.7 \\
\hline & & 12 & 10 & 2700 & 3900 & 3240 & 14.7 \\
\hline \multirow{6}{*}{ Poplar } & \multirow{3}{*}{ PVAc } & 4 & 10 & 1700 & 2400 & 2190 & 11.8 \\
\hline & & 8 & 10 & 2100 & 2800 & 2510 & 7.9 \\
\hline & & 12 & 10 & 2800 & 4000 & 3300 & 13.9 \\
\hline & \multirow{3}{*}{ PU } & 4 & 10 & 1300 & 2000 & 1620 & 14.5 \\
\hline & & 8 & 10 & 2100 & 3100 & 2480 & 13.0 \\
\hline & & 12 & 10 & 2600 & 3600 & 3170 & 13.4 \\
\hline \multirow{6}{*}{ Fir } & \multirow{3}{*}{ PVAc } & 4 & 10 & 1500 & 2300 & 1920 & 13.4 \\
\hline & & 8 & 10 & 1900 & 2700 & 2180 & 10.6 \\
\hline & & 12 & 10 & 2800 & 4100 & 3420 & 13.3 \\
\hline & \multirow{3}{*}{ PU } & 4 & 10 & 1100 & 1500 & 1330 & 11.2 \\
\hline & & 8 & 10 & 1100 & 1600 & 1340 & 11.8 \\
\hline & & 12 & 10 & 2400 & 3700 & 2940 & 16.2 \\
\hline
\end{tabular}

Table 3. Ultimate Force Results Under Diagonal Compression for Box-type Joints

\begin{tabular}{|c|c|c|c|c|c|c|c|}
\hline $\begin{array}{l}\text { Wood } \\
\text { Species }\end{array}$ & $\begin{array}{c}\text { Adhesive } \\
\text { Type }\end{array}$ & $\begin{array}{c}\text { Number of } \\
\text { Teeth }\end{array}$ & $\begin{array}{c}\text { Number } \\
\text { of } \\
\text { Tests }\end{array}$ & $\begin{array}{l}\text { Minimum } \\
\text { Value (N) }\end{array}$ & $\begin{array}{l}\text { Maximum } \\
\text { Value }(N)\end{array}$ & $\begin{array}{l}\text { Mean } \\
\text { Value } \\
(\mathrm{N})\end{array}$ & $\begin{array}{c}\text { Coefficients } \\
\text { of Variation } \\
(\%)\end{array}$ \\
\hline \multirow{6}{*}{$\begin{array}{l}\text { Scotch } \\
\text { Pine }\end{array}$} & \multirow{3}{*}{ PVAc } & 4 & 10 & 500 & 700 & 560 & 15.1 \\
\hline & & 8 & 10 & 400 & 700 & 570 & 16.6 \\
\hline & & 12 & 10 & 900 & 1200 & 1120 & 11.6 \\
\hline & \multirow{3}{*}{ PU } & 4 & 10 & 300 & 400 & 350 & 15.06 \\
\hline & & 8 & 10 & 600 & 800 & 660 & 12.8 \\
\hline & & 12 & 10 & 1000 & 1400 & 1180 & 11.2 \\
\hline \multirow{6}{*}{ Poplar } & \multirow{3}{*}{ PVAc } & 4 & 10 & 500 & 700 & 610 & 12.1 \\
\hline & & 8 & 10 & 600 & 700 & 640 & 8.1 \\
\hline & & 12 & 10 & 900 & 1300 & 1100 & 12.1 \\
\hline & \multirow{3}{*}{ PU } & 4 & 10 & 400 & 600 & 500 & 13.3 \\
\hline & & 8 & 10 & 700 & 1000 & 850 & 11.4 \\
\hline & & 12 & 10 & 1100 & 1600 & 1320 & 13.6 \\
\hline \multirow{6}{*}{ Fir } & \multirow{3}{*}{ PVAc } & 4 & 10 & 400 & 600 & 530 & 12.7 \\
\hline & & 8 & 10 & 400 & 600 & 460 & 15.2 \\
\hline & & 12 & 10 & 900 & 1200 & 1020 & 10.1 \\
\hline & \multirow{3}{*}{ PU } & 4 & 10 & 300 & 400 & 350 & 15.1 \\
\hline & & 8 & 10 & 400 & 600 & 480 & 13.2 \\
\hline & & 12 & 10 & 300 & 500 & 410 & 13.9 \\
\hline
\end{tabular}

\section{Analyses for the Moment Capacities under Diagonal Tension}

Multiple variance analysis was performed on the calculated moment capacity data obtained from a total of 180 specimens for determining the effect of wood species, adhesive type, number of teeth. M-STAT-C software was used for statistical analyses. The results of the analysis of variance are shown in Table 4. 
Table 4. Summary of the ANOVA Results for Moment Capacities under Tension

\begin{tabular}{|c|c|c|c|c|c|}
\hline Source & $\begin{array}{c}\text { Degrees } \\
\text { of } \\
\text { Freedom }\end{array}$ & $\begin{array}{c}\text { Sum of } \\
\text { Squares }\end{array}$ & $\begin{array}{c}\text { Mean } \\
\text { Squares }\end{array}$ & F-value & $\begin{array}{c}\text { Prob. } \\
\text { (sig. 5\%) }\end{array}$ \\
\hline Wood species (A) & 41407.9 & 2 & 20704.0 & 33.46 & .000 \\
\hline Adhesive type (B) & 30467.6 & 1 & 30467.6 & 49.24 & .000 \\
\hline Number of teeth (C) & 142256.3 & 2 & 71128.1 & 114.95 & .000 \\
\hline $\mathrm{A} \times \mathrm{B}$ & 5242.0 & 2 & 2621.0 & 4.24 & .016 \\
\hline $\mathrm{A} \times \mathrm{C}$ & 5428.0 & 4 & 1356.9 & 2.19 & $.072^{*}$ \\
\hline $\mathrm{B} \times \mathrm{C}$ & 2537.0 & 2 & 1268.5 & 2.05 & $.132^{*}$ \\
\hline $\mathrm{A} \times \mathrm{B} \times \mathrm{C}$ & 5945.9 & 4 & 1486.5 & 2.40 & $.052^{*}$ \\
\hline Error & 100245.5 & 162 & 618.8 & & \\
\hline Total & 2925278.3 & 179 & & & \\
\hline
\end{tabular}

*: Not significant

The effects of the main factors including wood species $(A)$, adhesive type $(B)$, and number of teeth $(C)$ were found to be statistically significant at the level of 0.05 . All twoway and three-way interactions except for wood species $\times$ adhesive type $(A \times B)$ were not statistically significant $(p \leq 0.05)$. The least significant difference mean comparisons procedure at 5\% significance level were performed to determine the mean differences of moment capacities under diagonal tension with respect to the main effects and a significant interaction.

When the comparison results of wood species were examined, it was seen that the highest moment capacity was obtained for Scotch pine. The moment capacities of poplar and fir specimens were much lower. The density of Scotch pine wood was higher than the density of the other woods used in the experiments. Mean comparison results according to wood species are given in Table 5 .

Table 5. Mean Comparison Results of Moment Capacities under Tension for Wood Species

\begin{tabular}{|c|c|c|}
\hline \multirow{2}{*}{ Wood species } & \multicolumn{2}{|c|}{ Moment under tension (Nm) } \\
\cline { 2 - 3 } & $\mathrm{X}$ & $\mathrm{HG}$ \\
\hline Scotch pine & 139.2 & $A$ \\
\hline Poplar & 118.7 & $B$ \\
\hline Fir & 102.2 & $C$ \\
\hline
\end{tabular}

When the effect of adhesive was examined, PVAc specimens were more successful than PVAc specimens. The PU adhesive expands its volume after being applied to the wood material. Mean comparisons of moment capacities with respect to adhesives are given in Table 6.

Table 6. Mean Comparison Results of Moment Capacities under Tension for Adhesive Type

\begin{tabular}{|c|c|c|}
\hline \multirow{2}{*}{ Adhesive type } & \multicolumn{2}{|c|}{ Moment under tension (Nm) } \\
\cline { 2 - 3 } & $\mathrm{X}$ & $\mathrm{HG}$ \\
\hline PVAc & 133.0 & $A$ \\
\hline PU & 106.7 & $B$ \\
\hline
\end{tabular}


When the effect of number of teeth was examined, 12-tooth joints yielded better results. As the number of teeth increased in the corner joints, the resistance of the joint increased. This situation may be due to the increase in surface area involved in the adhesion in 12-tooth joints. However, results did not demonstrate any directly linear relationship of moment capacities vs. number of teeth; i.e., performance of box-joints did not drastically increase with an increase from 4-tooth to 8 or 12-tooth. Moment capacities according to the number of teeth are given in Table 7.

Table 7. Mean Comparison Results of Moment Capacities under Tension for Number of Teeth

\begin{tabular}{|c|c|c|}
\hline \multirow{2}{*}{ Number of teeth } & \multicolumn{2}{|c|}{ Moment under tension (Nm) } \\
\cline { 2 - 3 } & $\mathrm{X}$ & $\mathrm{HG}$ \\
\hline 4 & 93.0 & $\mathrm{C}$ \\
\hline 8 & 108.2 & $B$ \\
\hline 12 & 158.8 & $A$ \\
\hline
\end{tabular}

Mean comparisons for two-way and three-way interactions were not provided due to the fact that all interactions were insignificant except for wood species $\mathrm{x}$ adhesive interaction. However, a multiple comparison with a lower bound confidence interval is provided in Table 8 to draw a complete picture for results. Overall, the best result was obtained in 12-tooth joints with PVAc adhesive in Scotch pine. The lowest result was obtained in 4-tooth joints with PU adhesive in fir.

Table 8. Multiple Comparison Results under Tension for Wood Species $x$ Adhesive Type $\times$ Number of Teeth Interaction

\begin{tabular}{|c|c|c|c|c|c|}
\hline Wood species & Adhesive & Number of teeth & Mean & Std. Error & $\begin{array}{c}\text { 95\% Confidence } \\
\text { Interval } \\
\text { Lower Bound }\end{array}$ \\
\hline \multirow{6}{*}{ Fir } & \multirow{3}{*}{ PU } & 12 & 137.15 & \multirow{18}{*}{7.86} & 121.62 \\
\hline & & 4 & 62.04 & & 46.51 \\
\hline & & 8 & 62.51 & & 46.98 \\
\hline & \multirow{3}{*}{ PVAc } & 12 & 159.54 & & 144.01 \\
\hline & & 4 & 89.57 & & 74.03 \\
\hline & & 8 & 101.70 & & 86.16 \\
\hline \multirow{6}{*}{ Poplar } & \multirow{3}{*}{ PU } & 12 & 147.88 & & 132.35 \\
\hline & & 4 & 75.57 & & 60.04 \\
\hline & & 8 & 115.69 & & 100.16 \\
\hline & \multirow{3}{*}{ PVAc } & 12 & 153.95 & & 138.41 \\
\hline & & 4 & 102.16 & & 86.63 \\
\hline & & 8 & 117.09 & & 101.56 \\
\hline \multirow{6}{*}{ Scotch pine } & \multirow{3}{*}{ PU } & 12 & 151.15 & & 135.61 \\
\hline & & 4 & 89.10 & & 73.57 \\
\hline & & 8 & 121.76 & & 106.22 \\
\hline & \multirow{3}{*}{ PVAc } & 12 & 202.93 & & 187.39 \\
\hline & & 4 & 139.48 & & 123.95 \\
\hline & & 8 & 130.62 & & 115.09 \\
\hline
\end{tabular}

Analyses for the Moment Capacities under Diagonal Compression

Multiple variance analysis was performed on the data obtained from a total of 180 specimens for determining the effect of wood species, adhesive type, and number of teeth 
on moment capacities under compression. The results of the analysis of variance are shown in Table 9.

Table 9. Summary of the ANOVA Results for Moment Capacities under Compression

\begin{tabular}{|c|c|c|c|c|c|}
\hline Source & $\begin{array}{c}\text { Degrees of } \\
\text { freedom }\end{array}$ & $\begin{array}{c}\text { Sum of } \\
\text { squares }\end{array}$ & $\begin{array}{c}\text { Mean } \\
\text { squares }\end{array}$ & F-value & $\begin{array}{c}\text { Prob. } \\
\text { (sig. 5\%) }\end{array}$ \\
\hline Wood species $(A)$ & 30189.5 & 2 & 15094.8 & 15.80 & .000 \\
\hline Adhesive type $(B)$ & 3494.0 & 1 & 3494.0 & 3.66 & $.058^{*}$ \\
\hline $\begin{array}{c}\text { Number of teeth } \\
(C)\end{array}$ & 98946.6 & 2 & 49473.3 & 51.81 & .000 \\
\hline$A \times B$ & 5165.9 & 2 & 2582.9 & 2.70 & $.070^{*}$ \\
\hline$A \times C$ & 13506.1 & 4 & 3376.5 & 3.54 & .009 \\
\hline$B \times C$ & 8131.3 & 2 & 4065.7 & 4.26 & .016 \\
\hline$A \times B \times C$ & 6333.3 & 4 & 1583.3 & 1.66 & $.162^{*}$ \\
\hline Error & 154694.6 & 162 & 954.9 & & \\
\hline Total & 1133986.0 & 179 & & & \\
\hline
\end{tabular}

* Not significant

According to the results of this analysis, the effects of the main factors of wood species $(A)$ and number of teeth $(C)$ were found to be statistically significant, while adhesive $(B)$ was insignificant at the level of 0.05 . Three factor interactions of wood species $\times$ adhesive type $\times$ number of teeth $(A \times B \times C)$ were also statistically insignificant $(p \leq$ $0.05)$.

When mean comparisons of wood species were examined, the highest moment capacity was obtained in poplar specimens. The moment capacities of Scotch pine and fir were lower. Results according to wood species are given in Table 10.

Table 10. Mean Comparison Results of Moment Capacities under Compression for Wood Species

\begin{tabular}{|c|c|c|}
\hline \multirow{2}{*}{ Wood Species } & \multicolumn{2}{|c|}{ Moment under Compression (Nm) } \\
\cline { 2 - 3 } & $\mathrm{X}$ & $\mathrm{HG}$ \\
\hline Scotch pine & 69.0 & $B$ \\
\hline Poplar & 82.1 & $A$ \\
\hline Fir & 50.5 & $C$ \\
\hline
\end{tabular}

When the effect of adhesive was examined, PVAc adhesive was more successful than PU adhesive. Moment capacities with respect to adhesive used in experiments are given in Table 11.

Table 11. Mean Comparison Results of Moment Capacities under Compression for Adhesive Type

\begin{tabular}{|c|c|c|}
\hline \multirow{2}{*}{ Adhesive Type } & \multicolumn{2}{|c|}{ Moment under Compression (Nm) } \\
\cline { 2 - 3 } & $\mathrm{X}$ & $\mathrm{HG}$ \\
\hline PVAC & 71.6 & $A$ \\
\hline PU & 62.8 & $A$ \\
\hline
\end{tabular}

When the effect of number of teeth was examined; the moment capacities of the 12-tooth joints were the highest, while the moment capacities of the 4-tooth joints were the lowest. As the number of teeth increased, the strength of the joint was also increased. This 
situation may be due to the increase in surface area involved in the adhesion using 12-tooth joints. However, the relationship between number of teeth and moment capacities was not linear. As a matter of fact, the means for 4-tooth and 8-teeth were close to each other, even if they were not in the same homogeneity group. By contrast, there was a clear jump from 8 to 12 -tooth structures. The moment capacities according to the number of teeth are given in Table 12.

Table 12. Mean Comparison Results of Moment Capacities under Compression for Number of Teeth

\begin{tabular}{|c|c|c|}
\hline \multirow{2}{*}{ Number of Teeth } & \multicolumn{2}{|c|}{ Moment under Compression (Nm) } \\
\cline { 2 - 3 } & $\mathrm{X}$ & $\mathrm{HG}$ \\
\hline 4 & 45.1 & $\mathrm{C}$ \\
\hline 8 & 56.9 & $B$ \\
\hline 12 & 99.7 & $A$ \\
\hline
\end{tabular}

Multiple comparisons with a lower bound confidence interval are provided so as to draw a complete picture for results. Overall, the best result was obtained in 12-tooth joints with PVAc adhesive in poplar. The worst result was obtained in 4-tooth joints with PU adhesive in fir wood. Multiple comparisons of moment capacities are given in Table 13.

Table 13. Multiple Comparison Results under Compression for Wood Species $\times$ Adhesive Type $\times$ Number of Teeth interaction

\begin{tabular}{|c|c|c|c|c|c|}
\hline Wood species & Adhesive & Number of teeth & Mean & Std. Error & $\begin{array}{c}95 \% \text { Confidence } \\
\text { Interval } \\
\text { Lower Bound }\end{array}$ \\
\hline \multirow{6}{*}{ Fir } & \multirow{3}{*}{ PU } & 12 & 38.25 & \multirow{18}{*}{9.77} & 18.96 \\
\hline & & 4 & 32.66 & & 13.36 \\
\hline & & 8 & 44.78 & & 25.49 \\
\hline & \multirow{3}{*}{ PVAc } & 12 & 95.17 & & 75.87 \\
\hline & & 4 & 49.45 & & 30.15 \\
\hline & & 8 & 42.92 & & 23.62 \\
\hline \multirow{6}{*}{ Poplar } & \multirow{3}{*}{ PU } & 12 & 119.42 & & 100.13 \\
\hline & & 4 & 46.65 & & 27.35 \\
\hline & & 8 & 79.31 & & 60.01 \\
\hline & \multirow{3}{*}{ PVAc } & 12 & 130.62 & & 111.32 \\
\hline & & 4 & 56.91 & & 37.62 \\
\hline & & 8 & 59.71 & & 40.42 \\
\hline \multirow{6}{*}{ Scotch pine } & \multirow{3}{*}{ PU } & 12 & 110.09 & & 90.80 \\
\hline & & 4 & 32.66 & & 13.36 \\
\hline & & 8 & 61.58 & & 42.28 \\
\hline & \multirow{3}{*}{ PVAc } & 12 & 104.50 & & 85.20 \\
\hline & & 4 & 52.25 & & 32.95 \\
\hline & & 8 & 53.18 & & 33.88 \\
\hline
\end{tabular}

\section{CONCLUSIONS}

1. In diagonal tension: The highest performance in wood species was obtained with Scotch pine. The lowest performance was attained in fir. This can be attributed to the density of the Scotch pine being higher than the density of the other wood species 
tested in this study. In terms of number of teeth, the 12-tooth joints performed better than the 8-and 4-tooth joints. However, there was not clear linear relationship with respect to surface area. When the type of adhesive used in the experiments was examined, the PVAc was found to be more effective than PU.

2. In diagonal compression: The highest performance in wood species was obtained with poplar. The lowest performance was found in fir. In terms of number of teeth, the 12tooth joints performed better than the 8- and 4-tooth joints. As with the tension results, the effect of surface area was not linearly effective in the moment capacities. Thus, it is worth thinking about not utilizing many number of teeth, while a reasonable performance could be achieved with less. When various types of adhesives were examined, PVAc was more successful than PU.

3. The use of Scotch pine wood in the box-type corner joints subjected to moments under tension and the use of poplar wood in the joints subjected to moments under compression will increase the moment capacity of the joints. Increasing the number of teeth will improve the performance of box joints. Furthermore, the use of PVAc adhesive in the joints increased the strength of the bonding.

4. The results of the tests did not give a robust conclusion regarding the effect of number of teeth, which is contrary to the literature cited (Bustos et al. 2011 and Franke et al. 2014). Therefore, a detailed analysis with respect to surface area was not included in the study. However, specific consideration should be given to further analyze the surface area effect in order to give an idea to engineers and manufacturers as well as designers to decide whether it is worthwhile to increase the number of teeth in box joints.

\section{ACKNOWLEDGMENTS}

The authors would like to thank to Gazi University, Mugla Sitki Kocman

University, and Dekupe Wood R\&D Co. Ltd. for contributing to the success of this study.

\section{REFERENCES CITED}

ASTM D 143-83 (1983). "Standard methods of testing small clear specimens of timber," ASTM International, West Consthohocken, Philadelphia.

Atar, M., Keskin, H., Ustundag, A., Togay, A., Candan, Z., and Peker H. (2010). "Impacts of different joint angles and adhesives on diagonal tension performances of box-type furniture," BioResources 5(1), 324-342.

Ayarkwa, J., Hirashima, Y., and Sasaki, Y. (2000). "Effect of finger geometry and end pressure on the flexural properties of finger-jointed tropical African hardwoods," Forest Prod. J. 50(11-12), 53-63.

Bustos, C., Hernandez, H., Beauregard, R. E., and Mohammad, M. (2011). "Effect of end-pressure on the finger-joint quality of black spruce lumber: A microscopic analysis," Maderas-Cienc. Tecnol. 13(3), 319-328.

Chan, Y. (2002). "Joints (Engineering)" in: Classic Joints with Power Tools. Andy R. (ed.). Lark Books, Ashville, NC. ISBN: 1-57990-279-0 
Chen, G.-F., and Walworth, G. (2001). "Two-part polyurethane adhesive for structural finger joints," U. S. Patent No. 7655312B2.

Efe, H., and Imirzi, O. H. (2008). "Farklı birleştirme teknikleri ve değişik kalınlıklardaki levhalarla üretilmiş kutu-tipi mobilya köşe birleştirmelerinin moment taşıma kapasitesi (Moment capacities of case type furniture corner joints constructed of panels of various thicknesses and joinery techniques)," G.U. Journal of Polytechnic 11(1), 65-75.

Franke, B., Schusser, A., and Müller, A. (2014). "Analysis of finger joints from beech wood," in: World Conference on Timber Engineering, Quebec, Canada.

Freedman, David M. (1997). "Box making," in: Box Making Basics: Design, Technique, Projects, The Taunton Press, Newtown, CT. ISBN:1-56158-123-2

Kamboj, G., Zaborsky, V., and Girl, T. (2019). "Influence of geometry on the stiffness of corner finger joints," BioResources 14(2), 2946-2960.

Lange, D. A., Fields, J. T., and Stirn, S. A. (2001). "Finger joint application potentials for one-part polyurethanes," in: Proceedings of the Wood Adhesives 2000 Symposium, Madison, WI.

Murphey, W. K., and Rishel, L. E. (1972). "Finger joint feasibility in furniture production," Forest Prod. J. 22(2), 30-32.

Nicholls, T., and Crisan R. (2002). "Study of the stress-strain state in corner joints and box-type furniture using finite element analysis (FEA)," Holz als Roh- und Werkstoff 60, 66-71.

Ors, Y., Efe, H., and Kasal, A. (2003). "Bending strength of the through - dovetail corner joints on the case construction of furniture," G.U. Journal of Polytechnic 6(2), 497503.

TS 2471 (1976). "Wood - Determination of moisture content for physical and mechanical tests," Institute of Turkish Standards, Ankara.

TS 2472 (1976). "Wood - Determination of density for physical and mechanical tests," Institute of Turkish Standards, Ankara.

Ustundag, A. (2008). The Effects of Dovetail Angle on the Diagonal Compression and Tension Performance of Dovetail Corner Jolnts with Dovetails in Furniture, M.Sc. Thesis, Gazi University Institute of Science and Technology, Ankara.

Article submitted: December 31, 2019; Peer review completed: February 29, 2020;

Revised version received and accepted: March 13, 2020; Published: March 18, 2020.

DOI: 10.15376/biores.15.2.3136-3146 